\title{
Arthur D. Smith, MD: Humility, Hard Work, and Grace
}

\author{
Ralph V. Clayman, $\mathrm{MD}^{1}$ and John Denstedt, $\mathrm{MD}^{2}$
}

$\mathbf{I}_{\mathrm{s}}^{\mathrm{n}}$ n 1977, Arthur Smith and his family left the warmth of South Africa for the oft frozen tundra of Minnesota-the world of urology has never been the same. Within years of his arrival, the realm of endourology was launched. Despite many skeptics, Arthur prevailed and within short order there was a society (1984), a journal (1986), a definitive text (Smith's Endourology - 1996), and an annual series of world congresses and international videourology meetings. Not before nor since has a revolution of this nature taken hold of our specialty, transforming it from the highly invasive nature common to all other surgical specialties into a largely noninvasive/minimally invasive surgical discipline. And yet, Arthur, unlike most visionaries from Bozzini through Semm, was not disparaged nor expelled from any society. Why?

Herein lies the uniqueness of Arthur Smith. In seeking to create this new discipline of Endourology, at every turn, he freely shared his expertise with all who cared to learn. Never failing to encourage others to succeed, he drew ever larger circles, avoiding conflict through inclusion. Quick to praise and always with a warming smile, Arthur tirelessly inspired those around him to pursue their ideas and to seek excellence. With humility, hard-work, and grace, he created a subspecialty that welcomed everyone to join in the endeavor of taking the sting out of surgery. As a result, over the past 40 years, we have witnessed the evolution of Endourology and the attendant transformation of nearly all open urological surgery into noninvasive or minimally invasive procedures, much to the benefit of humankind. Concurrently Arthur educated a cadre of fa-

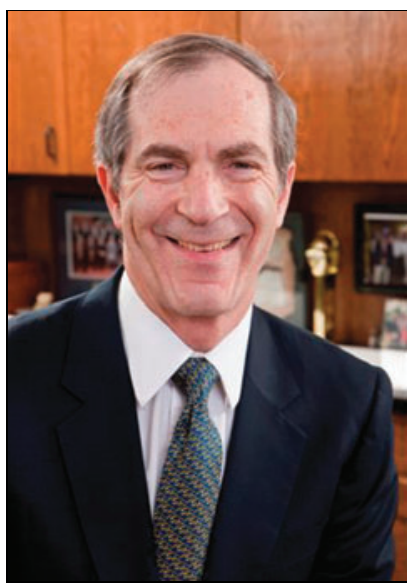

Ralph V. Clayman, MD

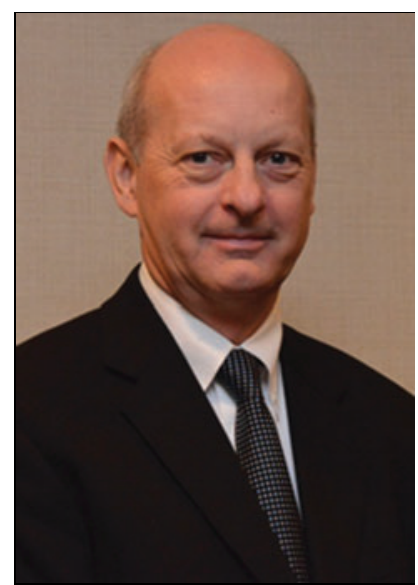

John Denstedt, $M D$ culty, fellows and residents who share his passion for pursuing all aspects of Endourology.

Arthur has also shown us all how one can successfully balance a massive career with a wonderful family. In short, Arthur's best move was marrying Kay. Kay has been his support and his love throughout, raising four very impressive children, all of whom have now married and provided Arthur and Kay with 13 grandchildren.

Today, thousands of urologists and millions of their patients owe a debt of gratitude to Arthur Smith, truly one of a kind in so many ways. And yet, as he would remind us all, the tale is not done: "You are only as good as tomorrow."

\footnotetext{
${ }^{1}$ Professor, Department of Urology, University of California, Irvine; Co-Editor-in-Chief, Journal of Endourology.

${ }^{2}$ Professor of Urology, Western University; Treasurer, Endourological Society; Executive Editor, Journal of Endourology.
} 


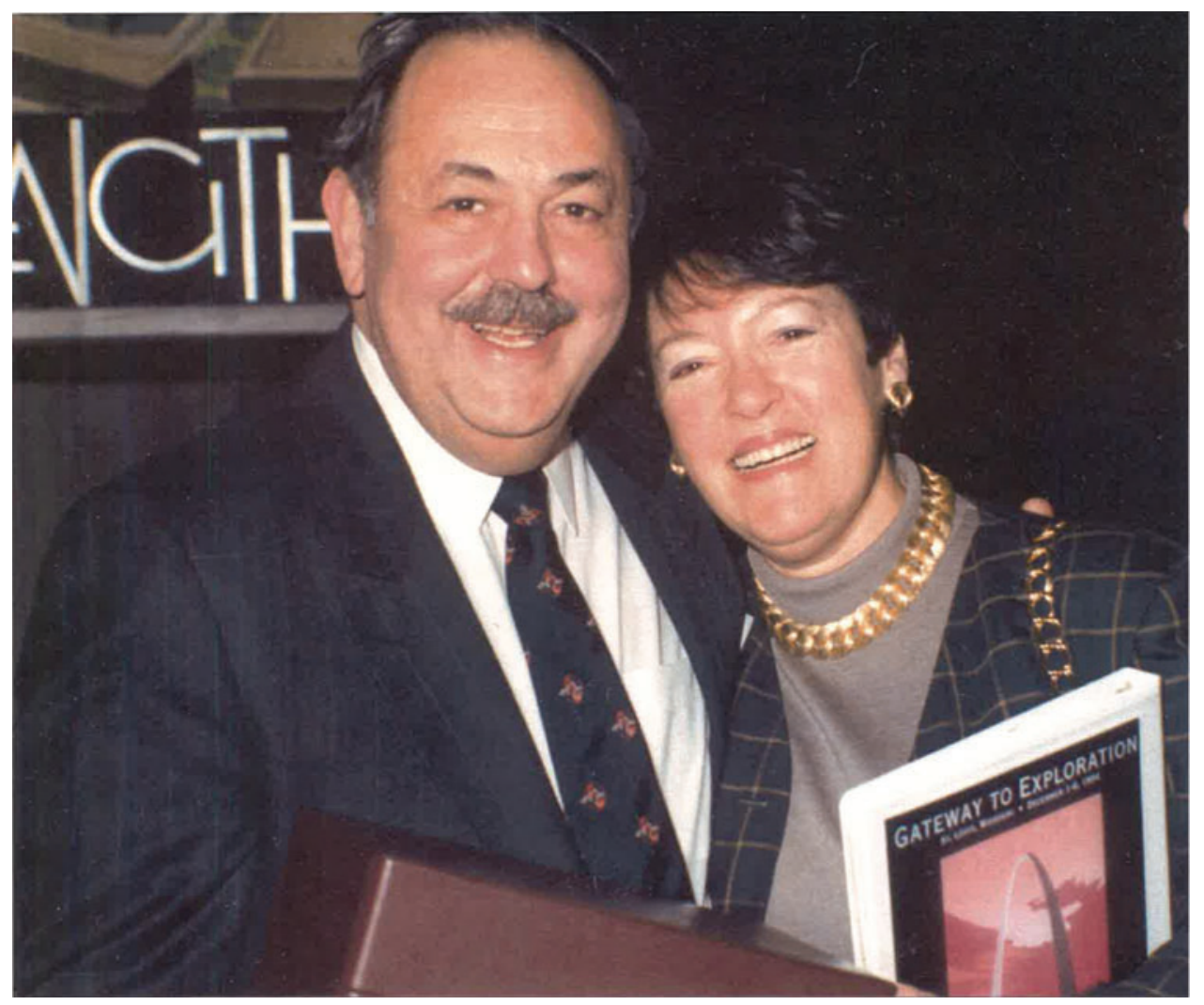

Arthur, passionate about his work, always wanted to make a difference.... and over the years he certainly contributed to his specialty. He is innovative and creative, and he pursued his ideas and goals with determination and persistence. Early on in his career he would persevere even in the face of criticism and opposition to unorthodox ideas.

On a personal note I'd like to say that, in spite of his dedication to his work and work-related projects, he has always maintained a superb balance between work commitments and time with the family, which we all enjoy. We have been fortunate to travel to many exotic and interesting places, meeting great people and having a lot of fun together. Equally wonderful are the times we spend with our family, whether it be trips with our children and grandchildren or all just enjoying various activities together.

Kay Smith 